of himself in his own affairs. Had it not been for the care and support afforded him during thirty-three years by his wife, he could scarcely have accomplished so much work on the Chrysomelidæ.

Poor health during the past two years had necessitated spells in hospital; but in recent months, and until his sudden death from heart-disease, he was working as usual, still full of zest and looking to the future.

Leslie Bairstow

\section{Mr. D. W. Amos, M.B.E.}

There are a number of instances of laymen who have quite unconsciously aided the progress of medical science, but extremely few who have, by the pursuit of parasitological studies, added to existing knowledge. Among this company must rank the name of $\mathrm{D}$. W. Amos, a business man who singlehanded undertook medical research of a high standard. He lived and worked in Suva, Fiji, for twenty-two years as manager of the Pacific Insurance Co. until 1941, when he retired at the age of sixty-four, and he died there on July 20, 1949, aged seventy-two.

As his contribution to the Allied effort during the Second World War, Amos volunteered to supervise the anti-mosquito work at Nandi Airport (the main airfield of Fiji). This service was designed to prevent the importation of anopheles mosquitoes from the Solomon. Islands by American bombers returning thence to their base in Fiji, and thus to guard these healthy islands against the introduction of malaria. During the course of his duties he studied entomology, paying special attention to the filariacarrying mosquito of these islands-Aëdes scutellaris pseudoscutellaris-based upon my original work in 1910-11. In a short space of time he produced a training manual on the mosquitoes of Fiji, written in Fijian, as well as in English, designed for the instruction of Fijians and Europeans employed in the anti-mosquito service. During the course of this work he discovered a species new to the Fijian list and also new to science, Aêdes (levua) geokusea Amos, 1944. In 1943, coming into contact with an American medical officer, J. I. Knott, whose work on filariasis is well known, Amos became familiar with Knott's method of abstracting blood from the veins for the diagnosis of filariasis. Thus armed, he embarked upon a thorough survey of the islands and, together with his teams, was responsible for some 63,000 blood examinations, so that statistics compiled from these sources are invaluable.

While working on this survey, Amos came to realize that the vital part of the life-cycle of $A \ddot{e} d e s$ scutellaris is the period of inactivity of this insect immediately after a meal on human blood, when it rests upon bushes or upon grass in the vicinity of native huts. His idea was to interrupt the cycle at this point by clearing and maintaining an open space around all the buris (huts) in Fijian villages, and, in addition, to keep down breeding by destroying tins, coconut shells and other water-holding receptacles, combined with the filling of tree holes and other breeding-places of this mosquito.

By training Fijians of the anti-mosquito service in these methods and by educating Fijian villagers in these precepts, he was eminently successful; so that, for the first time in its history, filariasis as a menace to the community has begun to recede in Fiji. At his death Amos was mourned as the 'Father of the Fijian people'.

Philip Manson-BaHr

\section{Prof. L. Breitfuss}

Whine on leave at Bad Pyrmont, the Nestor of polar research, Prof. Leonid Breitfuss, ex-councillor of State of the former Russian Empire, died on July 20, aged eighty-five. During his career of fifty years as a polar research worker, Prof. Breitfuss made a name for himself by his co-operation in the ten-year long Murmansk expedition undertaken by the Russian Empire in the nineties of the past century, and, in addition to that, by preparing and advising a great number of German and non-German polar expeditions. Among others were the expeditions in support of Nobile and Amundsen. He finally consolidated his name in polar research by the very important part he played in the foundation of the Intermational Society for the Exploration of the Arctic by Aircraft, called for short 'Aero-Arctic', of which Fridtjof Nansen, the famous Norwegian oceanographer, polar research worker and philanthropist, was the president. Though this Society existed only for a short time, it nevertheless gained a lasting importance from the well-known polar expedition with the German airship Graf Zeppelin in 1931.

Prof. Breitfuss, initially a biologist, remained faithful to his first love (his special field was research into sponges) and yet succeeded in consolidating his fame as a historian of polar research far beyond the boundaries of Germany. It was but a short time before his death that, working in Hamburg at the German Hydrographic Institute (of which he had been a member since 1946), he completed his last great work, the "Polar Review". This work will be published by instalments in the "Geographisches Jahrbuch". With its reference list of several thousand titles, and its contributions of recent date, the review will be a comprehensive compilation of sources of value to all engaged in polar research. Its usefulness will extend also to geographers, to geophysicists and to scientific workers in marine economies, for example, whaling.

Many honours both from at home and abroad were recently conferred on Prof. Breitfuss in the house of the German Hydrographic Institute where he had taken up residence, when, some six months ago, he celebrated his eighty-fifth birthday in surprisingly good health and vigour. He was descended from a great Russo-German family whose ancestors were oxpelled from Salzburg by Bishop Firmian at the time of the confessional wars, but had, by the generosity of the electors and kings of Brandenburg, been allowed to settle in East Prussia. Later on, the family had moved thence to Russia.

It is much to be regretted that Prof. Breitfuss did not survive to complete from the rich store of his knowledge the "Standard Work of Polar Research" as he called it, for to do so had been his most ardent desire for many years. With his death we have lost one of the few surviving representatives of the 'heroic era' of polar research.

\section{Dr. Brysson Cunningham}

The death occurred, on July 31, of Dr. Brysson Cunningham, an authority on dock and harbour engineering. He had contributed several descriptive articles to Nature on water-power developments in various parts of the world, all of them based on personal observations during his travels.

Dr. Cunningham was born in 1868 in Liverpool, and studied civil engineering at the University College 